\title{
Okamžiky rozhodnutí
}

\section{Jiří Olšovský}

\section{Envigogika 13 (1) - I nspirace / I nspiration}

Publikováno / Published 10. 8. 2018

DOI : $\underline{10.14712 / 18023061.570}$

\section{Abstrakt}

V určité chvíli je třeba jednat, proměnit i svůj postoj - skočit do proudu dění a snažit se ho ovlivnit. Jinak společenství může strhnout nepříznivý vír - octne se náhle nad propastí, dnes třeba nad propastí ztráty přirozeně přirodního prostředí.

\section{Klíčová slova}

Harmonie života; environmentální rizika; nihilismus; spontánní aktivita

\section{Abstract}

At a certain point, it is necessary to act, to change one's stance, to jump into the stream of events and to try to influence it. If not, society can suddenly find itself falling into the abyss: today we face the risk of the loss of the natural environment.

\section{Key Words}

Harmony of life; environmental risks; nihilism; spontaneous activity 
V určité chvíli je třeba jednat, proměnit i svůj postoj - skočit do proudu dění a snažit se ho ovlivnit. Jinak společenství může strhnout nepříznivý vír - octne se náhle nad propastí, dnes třeba nad propastí ztráty přirozeně prírodního prostředí. $V$ určitém okamžiku je třeba vskutku jednat, a i když to nebývá př́liš "výhodné", je zapotřebí se právě nyní „zahloubat do tuhého myšlení", jak psal Tomáš Garrigue Masaryk, a převést ho $v$ čin. $V$ jednom okamžiku se prokáže skutečná síla svobodného myslícího subjektu. Je pěkné proklamovat, že jsem silný; svou sílu je nutno ozřejmit ve skutečně tísnivé situaci a jít, jak se ř́ká, "do toho", svým myšlením probouzet z letargie, zastavit napríklad proces devastace, nastartovat naopak proces všeobecné regenerace a oživení života.

\section{Revoluce hlav a srdcí}

Hrozí-li vskutku nebezpečná situace, např́klad návrat k nějakému typu "staronové normalizace" ve společnosti či nějaký progresivistický úlet do „přímé" budoucnosti (nějaké hrůzné totality), pak zdravá myslivá a politická síla může sehrát významnou úlohu, může zamezit probublávající fatální katastrofě, např́klad úplnému zničení přírody, kdy nejsme s to jako lidstvo vyjít ze stávajícího nihilismu jejího nepřestajného ničení a plundrování. $Z$ nepř́znivé situace je pak snad možno uniknout jen radikální proměnou našeho myšlení a cítění, jak to po Havlíčkovi Borovském naznačoval i Masaryk. Sílu čistoty svého myšlení a cítění lze ozřejmit právě v toxickém prostředí, pravá síla se jasně osvědčí ve zprvu nepříznivě se vyvíjející situaci. Zvrátit nepříznivou situaci může ryze odhodlaná a odvážná síla, jen taková moc může převrátit mechanický chod událostí - např́ílad obrátit nepřiznivý trend rostoucího oteplování planety Země - směrem k příznivějšímu vývoji pro celek lidstva a života vůbec. $\checkmark$ demokratické společnosti to znamená probuzení živoucího pohybu $\mathrm{k}$ větší myslivé environmentální svobodě, kdy neraší cenzura, omezenost, byrokracie, autoritářství, plochý („pragmatický") manažerismus, nepatřičně dogmatické omezování myslivého běhu života.

Kdo ustoupí před svůdným zlem nemyšlení, stává se nutně spolupodílníkem tohoto zla. Temně lenivá síla, vedoucí ve svých důsledcích $\mathrm{k}$ devastaci životního prostředí (což je spjato s neschopností přivozovat záchranu pro veškerou existenci), vždy vyčkává za bukem své nemyslivé letargie, čeká na úplně zhroucenou situaci, aby mohla uskutečnit nějaký prvek dobově progresivistické (brutální, totalitární) představy. Přichází chvíle, která přímo vybízí k činu pochopení jednoty života, kdy se začíná jednat ve smyslu její záchrany. Pravdivé pochopení síly a jednoty života nakonec začíná vskutku jednat, $v$ zlhostejnělé situaci dobyvačného "všeobecného rưstu růstu" může živoucí myšlení ryze posílit, zbavit se pasivního nihilismu, osvědčit tak svou skutečnou velikost - jen se musí odhodlat $k$ činu a začít jednat třeba právě v duchu masarykovské revolty hlav a srdcí. Skutečná síla si musí uvědomit, že nenasytnému nihilistickému predátorovi v nás, který touží skutečnost a zem jen bezmezně vysávat, se nesmí zcela podléhat, ale šikovně s ním "vyjednávat", tj. naučit se opravdu myslet, cítit a jednat ve vztahu $k$ prírodě a bytí samému, aby nakonec náš destruktivní egoismus padl a objevil se čistě blankytný prostor svobodného oživení života na vždy zelené a modré planetě Zemi. Naakumulované napětí svůdného postpravdivého nihilistického "žvanění" se zas na dlouho rozptýlí.

\section{Síla zdraví z lesa}

Svou vyšší životní sílu je možné nacházet ve střetu se zdánlivě silnějším protivníkem. Dnes nejde jen o záchranu oceánů plných plastů a dalšího odpadu, o spásu pralesů, jde i o kultivaci vlastní nám svěrené země a půdy, aby z ní mohly růst kupříkladu právě spíše smíšené lesy, než jen smrkové monokultury pro těžbu dřeva. Může v nás vzrůstat schopnost 
zušlechtóvat náš svět, lépe ho „zavlažovat". I Goliáše našeho nenapravitelně racionalistického nihilismu Ize nakonec porazit, náš vnitřní bojovník se může postavit nepřiměřenému pobývání - jež je dobýváním - na zeměkouli, může se postavit zjevnému zlu, které jsme sami rozpoutali. Síla skutečného bojovníka mnohonásobně vzroste při odstraňování stresorů, jež dopadají díky lidské činnosti na přírodu, oceány, ovzduší a lesy. Vzdát se předem nebo pokračovat $v$ devastaci je projevem ne-síly, slabosti. Masaryk napsal, že jen pohybováním se v lese, v "šumném boří, Ize získat "kousek zdraví"; zde se Ize zahloubat i do vlastního nitra a nacházet $v$ něm „štěstí a poklid" - tak píše mladý Masaryk slečně Šemberové. $V$ lese, kde nalézal "blaho své", Ize i dobře myslet. A myšlení je dnes zapotřebí znovu intenzivně rozproudit, aby se dostalo z omamné šedi průměrnosti a diletantismu. Svobodný tok života se opět rozproudí, napojíme-li se na opravdovou sílu bytí samého. 